\title{
DENTAL CROWN BIOMINERALIZATION DURING ITS HISTOGENESIS
}

10.36740/WLek202012110

\author{
Oleksij P. Kostyrenko, Nataliia I. Vynnyk, Mykhailo M. Koptev, Petro A. Hasiuk, Maksym I. Skrypnyk, \\ Alevtyna M. Bilous, Serhii A. Proskurnya \\ UKRAINIAN MEDICAL STOMATOLOGICAL ACADEMY, POLTAVA, UKRAINE
}

\begin{abstract}
The aim: The paper was aimed at the study of the biomineralization processes of a permanent dental crown in the postnatal period of histogenesis. Materials and methods: The study involved 30 culled puppies aged 30-40 days. To study the histogenesis of the germs of the permanent tooth from the cuticular epithelium in the postnatal period microscopic, electron microscopic, immunohistochemical methods of study have been used.

Results: The studies show that in the postnatal period, the maturation of the germ of a permanent tooth starts with the synthesis of cells of the cuticular epithelium of the organic stroma, capable of subsequent mineralization. Differentiation of the proameloblasts, located on the surface of the dental papillary mesenchyma, at the early stages of histogenesis, is strongly associated with the appearance of a specific protein taftelin. Origination of secretory ameloblasts, which produce the protein enamelin, triggers the process of secondary biomineralization of the enamel. The terminal processes of the secretory ameloblasts produce the protein in the form of layers that overlap each other at a certain angle. Such layering of the structures of enamel and dentin contributes to the S-shaped maturation of the hard tooth tissues, strengthening them considerably. At the follicle stage, maturation of the dental crown, coated with cuticular epithelium, occurs. Invaginations of the cuticular epithelium form a characteristic topography of the dental crown, and enamel projections are further formed by the ameloblasts. Epitheliocytes of the inner layer of the enamel organ have desmosomal connections that allow the filtration of the salivary fluid at the stage of the enamel trophism.

Conclusions: The findings of the study suggest that, normally, due to the cuticular epithelium, filtration of the salivary fluid occurs with protein deposition on it and subsequent infiltration of the calcium salts into the subjacent enamel.
\end{abstract}

KEY WORDS: histogenesis, enamel, dentine, biomineralization, cuticular epithelium

Wiad Lek. 2020;73(12 p. I):2612-2616

\section{INTRODUCTION}

Biomineralization of the enamel and dentin is a complex, dynamic and stepwise process, characterized not only by the mineralization but also by the demineralization of the persistent hard tooth tissues [1-7]. In the embryonic period, the origination of the germ of the tooth from the cuticular epithelium occurs by the stepwise histogenesis and the differentiation of certain cellular elements that initially synthesize the organic stroma capable of mineralization and subsequent formation of the hard tooth tissues [8]. A large number of publications are devoted to the process of biomineralization of enamel and dentin in embryogenesis and in the postnatal period of histogenesis, but the variability and mosaicity of the findings obtained by the researchers, the lack of comprehensive description of this phenomenon require further fundamental research [9-16].

\section{THE AIM}

The paper was aimed at the study of the biomineralization processes of a permanent dental crown in the postnatal period of histogenesis.

\section{MATERIALS AND METHODS}

The study of the process of development of the germs of permanent frontal teeth and premolars involved 30 culled puppies aged 30-40 days (postnatal period of development), which, with respect to bioethical requirements, were taken from the owners as biological material for further pathomorphological study. After removal of the mandible, the specimens were fixed in $10 \%$ neutral formalin solution. Subsequently, after decalcification with trilon B, fragments of the jaw were cut off selectively. After paraffin harness, micropreparations, stained with hematoxylin and eosin were made for light microscopy and immunohistochemical study during which intercellular adhesion was determined at the stages of differentiation of the epithelial cells by the reaction of E-cadherin protein. The findings were registered on the Olympus BX 41 microscope.

To study the structure of hard tissues of the frontal group of teeth that were extracted in 20 subjects, light and electron microscopy of the sections were performed. The sections were prepared according to the conventional method, making longitudinal cuttings of teeth fixed in $10 \%$ neutral formalin solution. 


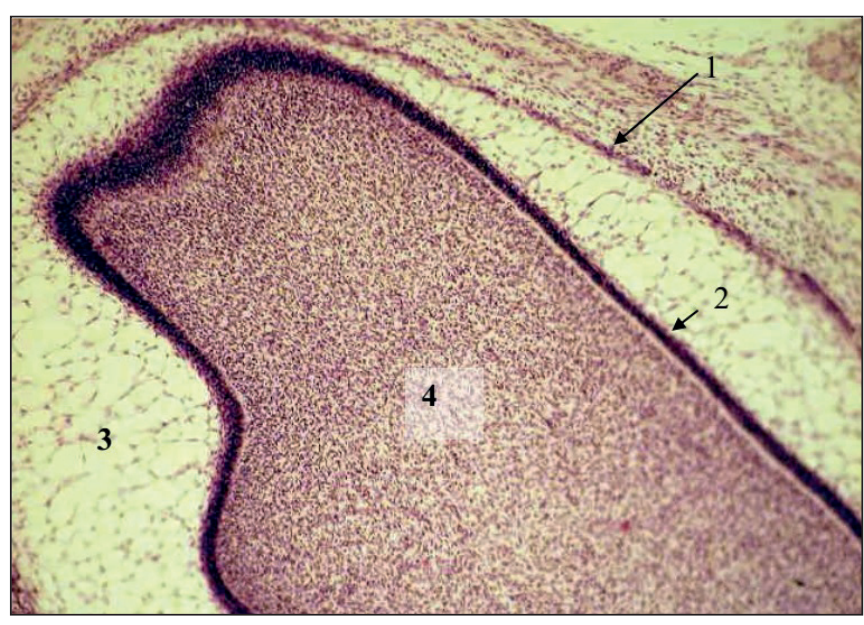

Fig. 1. Maturation of the enamel organ at the stage of cupula. 1 - inner epithelial layer; 2 - the layer of proameloblasts (the inner layer); 3 - pulp of the enamel organ; 4 - dental papilla. H\&E stain. 200×magnification.

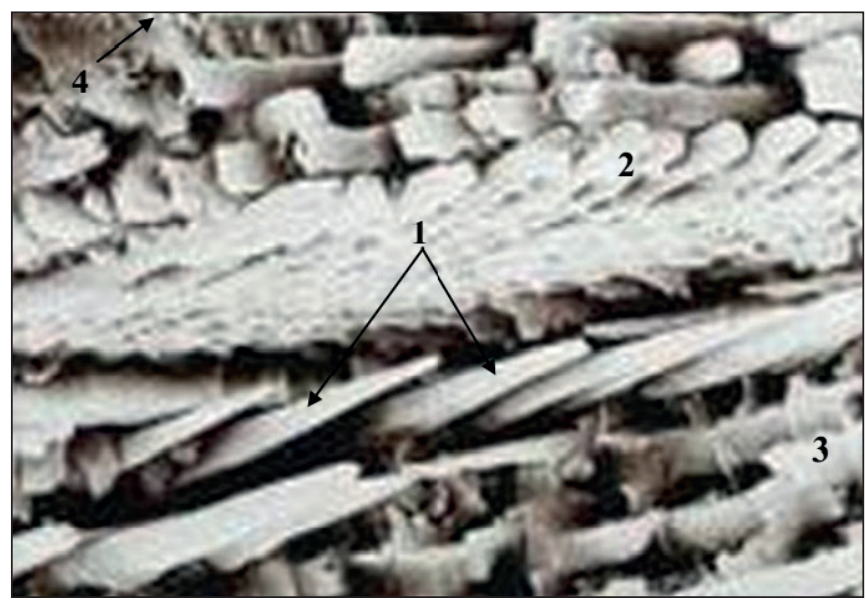

Fig. 3. Electronogram of the longitudinal split of the enamel on the boundary with dentine layer: 1 - transverse path of the picket-fence crystals of the enamel; 2 -laminar structures of the intermediate zone; 3 - dentine structures; 4 - remains of the cuticular epithelium. 5000×magnification.

\section{RESULTS}

At the first stage of the histogenesis, the cervix of the enamel organ is formed from the primary oropharynx, lined by the cuticular epithelium, which is a multi-layer strip containing cytokeratin in its cells. The latter forms the germ of the tooth in the form of a cupula (Fig. 1). During histogenesis at the cupula stage, proameloblasts are localized on the surface of the mesenchyma of the dental papilla, the inner part of which is represented by the pulp of the enamel organ in the form of remains of the cuticular epithelium. The outer layer of the enamel organ forms the Hertwig's epithelial root sheath. Noteworthy, the morphogenetic processes of differentiation of the proameloblasts at the early stages of histogenesis are strongly associated with the appearance of a specific protein, called taftelin.

At the pileus stage on the surface of the formed terminal dentin, which has a positive PAS-reaction, secretory ameloblasts are formed. They are localized perpendicular to the mature dentin layer, and their processes are di-

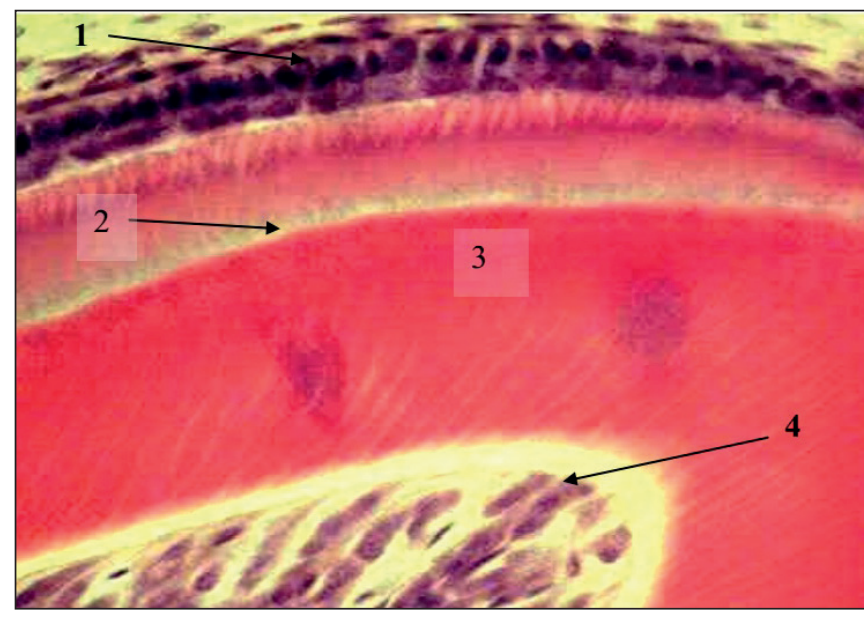

Fig. 2. Enamel organ at the stage of the secondary biomineralization of the enamel. 1 - secretory ameloblasts; 2 - Tomes' processes; 3 - layer of the mantle dentin; 4 - odontoblasts. H\&E stain. 400×magnification.

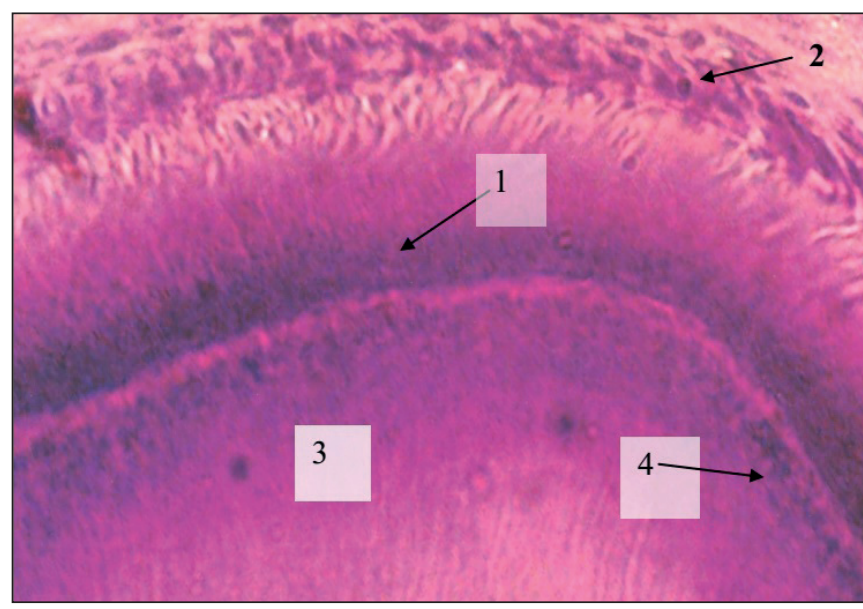

Fig. 4. The formation of the chewing surfaces of the molars and premolars at the dental follicle stage: 1 - biomineralized enamel; 2 - poorly differentiated ameloblasts; 3 - mantle dentine layer; 4 - odontoblasts. H\&E stain. $400 \times$ magnification.

rected differently: transverse in the area of the cusps and perpendicular in the area of the dental cervix. Terminal processes of the secretory ameloblasts produce protein, called enamelin, which, in our opinion, triggers the process of the secondary biomineralization of the enamel. It is confirmed by the presence of red oxyfilic substances (hematoxylin and eosin stain) on the terminal processes of the secretory ameloblasts adjoining the terminal portion of the dentine (Fig. 2).

Our hypothesis is partially confirmed by the electron microscopy on the boundary of the terminal processes of the secretory ameloblasts and partially formed odontoblastic processes, which respectively formed the picket-fence and laminar crystalline structures (Fig. 3).

The figure shows the ameloblastic processes, which have a transverse path and a fine filamentous surface structure, whereas the odontoblastic processes have a homogeneous granular structure of the surface. Eventually, in the intermediate zone filamentous or glomerular structures that resemble 


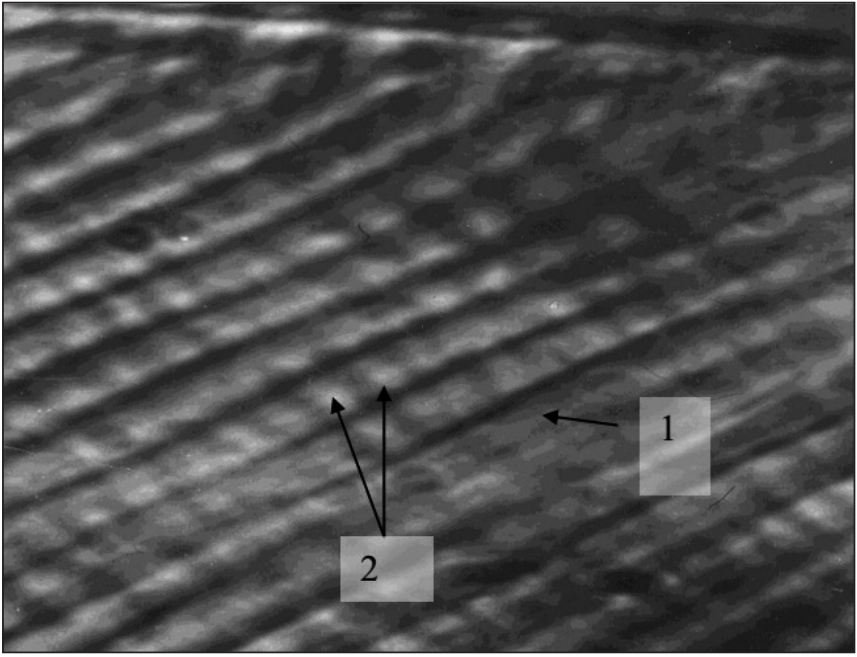

Fig. 5. Electronogram of the longitudinal section of the enamel. 1 - dark longitudinal stripes of enamel fasciculi; 2 - clear diversity of colors of transverse sections of the enamel fasciculi. 1000×magnification.

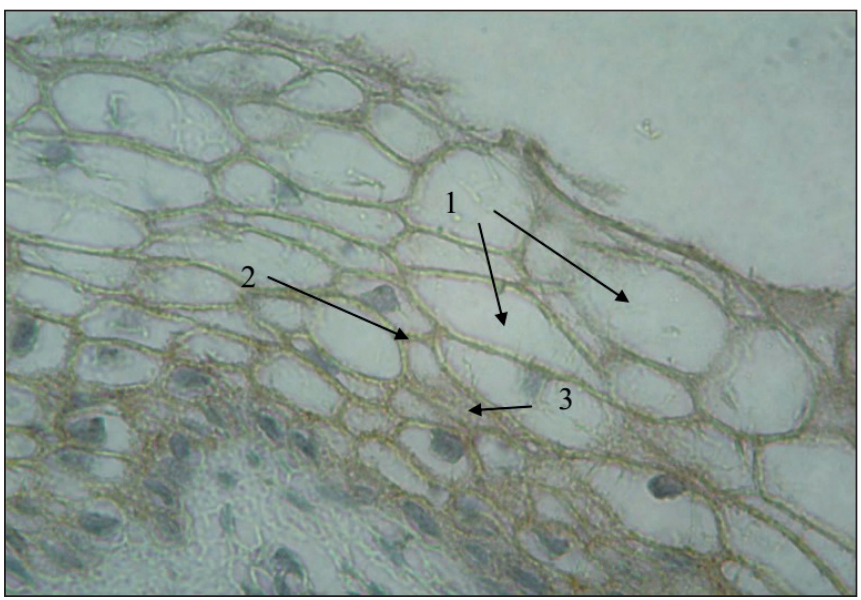

Fig. 7. Structure of the cuticular epithelium. 1 - keratinized epithelial cells; 2 -desmosomal connections between epithelial cells; 3 - granules of keratohyalinum. Immunohistochemical reaction with E-cadherin marker. 800×magnification.

calcium octaphosphate are located. Apparently, at the pileus stage, the terminal processes of the secretory ameloblasts have different patterns of the path. The path of future fasciculi of the enamel prisms is formed by these processes. At the same time, the synthesis of the precursor, namely, calcium octaphosphate, occurs due to production of enamelin.

At the follicle stage, dental crown is formed, which has no roots. The follicle is coated with a cuticular epithelium of the outer layer of the enamel organ. Beneath is a cholesterol-loaded liquid, which gradually replaces the pulp of the enamel organ, which is then reduced. At the follicle stage, histogenesis occurs in different classes of teeth with some differences. Thus, in the frontal teeth, the follicle is formed by an outer layer of the cuticular epithelium with its atrophied pulp located beneath. The formation of the molar or premolar crown occurs at the stage of the follicle. Obviously, the invaginated areas of the crown are formed by the growing-in of the cuticular epithelium of the pulp of the enamel organ.

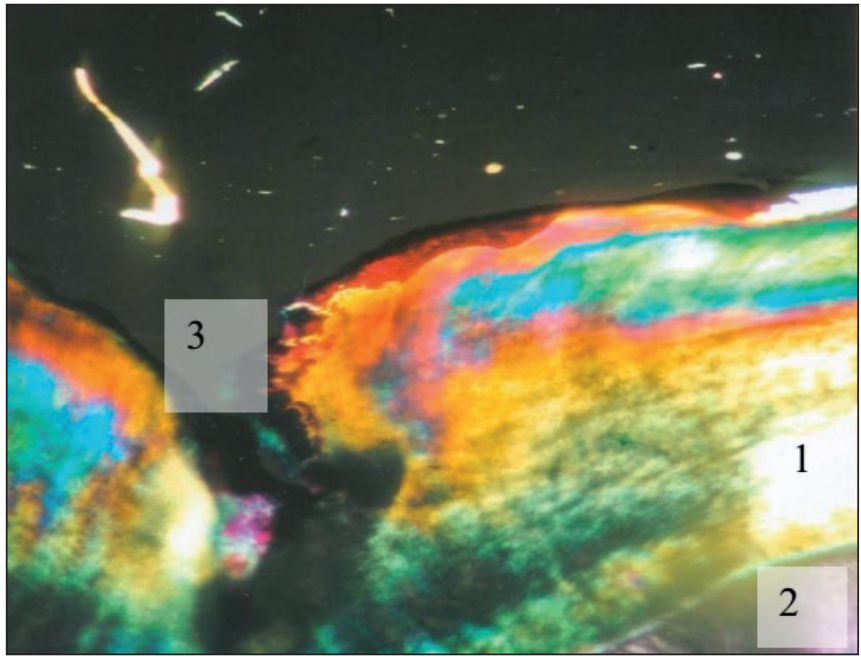

Fig. 6. Enamel anisomorphy. 1 - enamel; 2 - mantle dentine; 3 - enamel sulcus. Native longitudinal section of the enamel. $32 \times$ magnification.

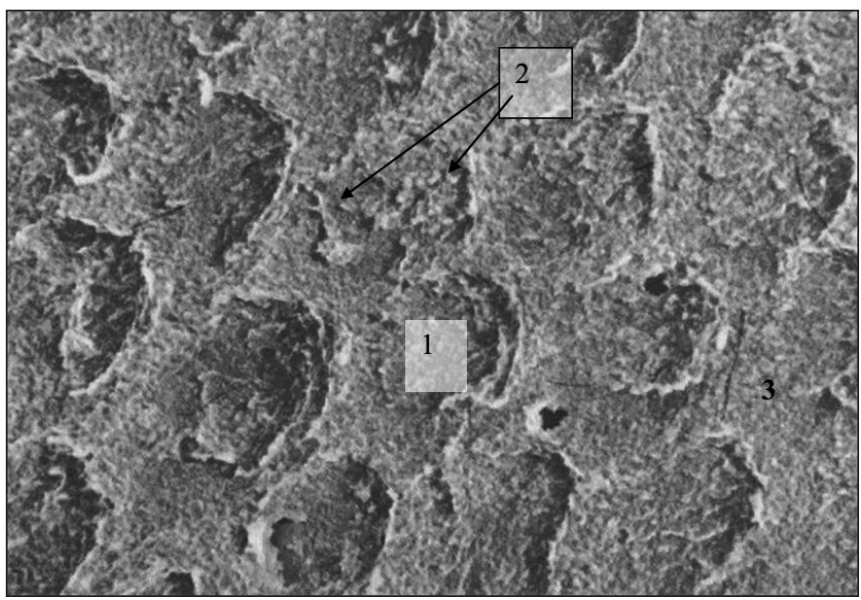

Fig. 8. Electronogram of the transverse section of the enamel. 1 - enamel prisms; 2 - fine-granular filamentary structures; 3 - mineralized surface of the enamel. $1000 \times$ magnification.

We conducted a study of the process of follicle maturation, which occurs during the formation of the chewing surface at the stage of histogenesis. It has been found that multiple projecting and invaginated areas are formed, on the one hand, by the cuticular epithelium of the pulp of the enamel organ, and, on the other hand, by the enamel projections formed by the ameloblasts. The projecting areas of the dental crown are formed by the enamel prisms, formed by the ameloblasts (Fig. 4).

It has been established that at the follicle stage a biomineralized enamel of dark-purple color is formed along the enamel-dentinal boundary. In the intermediate layer, biomineralization is less pronounced. Eventually, the third outer layer, adjacent to the cuticular epithelium, is represented by the poorly differentiated ameloblasts. Some ameloblasts produce clear processes, and the other ones are located parallel to the surface of the cuticle, occupying horizontal position. The nuclei of these ameloblasts are diminished, indicating their atrophy. They form spiral 
fasciculi in the cusps, bridging constructions on the lateral sides and in the cervix the S-shaped invaginations are separated by the lamellae. The histogenesis of enamel prisms at the follicle stage is provided by two types of differentiated ameloblasts. The first type of ameloblasts has dense connections on the apical surfaces, from which the fine granules of the protein amelogenin are secreted. This protein promotes deposition of crystals of hydroxyapatite due to modification and dehydration. Due to this process the second type of ameloblasts has an expanded apical surface, and in their cytoplasm hydropic vacuoles are found.

Due to the function of two types of ameloblasts, enamel prisms have a transverse diversity of colors with alternating clear and dark strips (Fig. 5). Anisomorphy, i.e., a change in color in polarized microscopy, is characteristic to the latter (Fig. 6).

Once the formation of enamel prisms was completed, ameloblasts atrophied and form a bright cortical enamel layer.

Immunohistochemical studies show that individual epithelial cells of the inner layer undergo keratinization. However, desmosomal connections are noted between the individual cells. Through these fissures, salivary fluid is filtered (Fig. 7).

It has been verified by the electron microscopic study. Thus, epitheliocytes with varying degree of keratinization are conjoined by the connections of different widths. Moreover, it is based on the immunohistochemical reaction of E-cadherin, during which intercellular connections are clearly detected using desmosomes, as well as the presence of cytoplasm and granules of keratohyalinum.

Consequently, in the structural and functional aspect, pits and fissures have the property of filtering the salivary fluid from the protein component and, due to the calcium salts, can provide biomineralization of the enamel that is evidenced by the electron-microscopic data (Fig. 8).

The study revealed the cuticular epithelium, a protein deposit in the form of fine-granular and filamentary structure in preservation of desmosomes. This suggests that, normally, due to the cuticular epithelium, filtration of the salivary fluid occurs with deposition of protein deposit on it and further infiltration of the calcium salts into the subjacent enamel. Taking into account the importance of the cuticular epithelium in the filtration of salivary fluid, we can assume that, normally, invaginated areas of different levels correspondingly have a different degree of filtration: maximum in the pits, maximum or moderate in the grooves and minimal in the fissures.

\section{DISCUSSION}

Thus, during embryogenesis, the formation of the dental germ from the cuticular epithelium occurs by the stepwise histogenesis and differentiation of certain cellular elements, which initially synthesize the organic stroma capable of mineralization and the subsequent formation of hard tooth tissues.

At the first stage of the formation of the enamel organ at the cupula stage proameloblasts are localized on the surface of the mesenchyma of the dental papilla, the inner part of which is represented by the pulp of the enamel organ in the form of remains of the cuticular epithelium. Morphogenetic processes of differentiation of proameloblasts at the early stages of embryogenesis are strongly associated with the appearance of a specific protein, called taftelin. The next stage is characterized by the origination of the secretory ameloblasts, which produce the protein called enamelin, triggering the process of secondary biomineralization of the enamel. The terminal processes of the secretory ameloblasts produce the protein in the form of layers that overlap each other at a certain angle. Such layering of the structures of enamel and dentin contributes to the S-shaped formation of the hard tooth tissues, strengthening them considerably. Importantly, shock-absorbing function is characteristic to the mature hard tooth tissues, contributing to their trophism during chewing of food. Electron microscopy confirms the above, showing the arrangement of the terminal processes of secretory ameloblasts and partially formed odontoblastic processes in the form of picket-fence and laminar crystalline structures.

At the follicle stage dental crown is formed, coated with a cuticular epithelium. Certain invaginations of the cuticular epithelium form a specific topography of the dental crown. Multiple projecting and invaginated areas are formed, on the one hand, by the cuticular epithelium of the pulp of the enamel organ, and, on the other hand, by the enamel projections formed by the ameloblasts. The projecting areas of the dental crown are formed by the enamel prisms, formed by the ameloblasts. The formation of enamel prisms at the follicle stage is provided by the synthesis of the granules of the amelogenin protein. This protein promotes deposition of crystals of hydroxyapatite due to modification and dehydration. Epitheliocytes of the inner layer of the enamel organ have desmosomal connections that allow the filtration of the salivary fluid at the stage of the enamel trophism, forming a protein deposit in the form of fine-granular and filamentary structure in preservation of desmosomes.

\section{CONCLUSIONS}

1. During dental histogenesis the crown is formed at the follicle stage.

2. During maturation the dental crown is coated with cuticular epithelium invaginations of which form a specific topography.

3. Multiple projections and invaginations are caused, on the one hand, by the cuticular epithelium of the pulp of the enamel organ, and, on the other hand, by the enamel projections formed by the ameloblasts.

4. Projecting areas of the dental crown are originated due to enamel prisms, formed by ameloblasts, synthesizing the granules of the amelogenin protein. The protein promotes deposition of crystals of hydroxyapatite due to modification and dehydration.

5. Epithelial cells of the inner layer of the enamel organ filter the salivary fluid at the stage of enamel trophism due to desmosomal connections. 


\section{REFERENCES}

1. Gelse K., Poschl E., Aigner T. Collagens-structure, function, and biosynthesis. Adv Drug Deliv Rev. 2003; 55 (12): 1531-1546.

2. Lin C., Douglas W.H., Erlandsen S.L. Scanning electron microscopy of type I collagen at the dentin-enamel junction of human teeth. J Histochem Cytochem. 1993; 41 (3): 381-388.

3. Vallet-Regí M., González-Calbet J.M. Calcium phosphates as substitution of bone tissues. Prog Solid State Chem. 2004; 32 (1-2): 1-31.

4. Boskey A., Young M., Kilts T., Verdelis K. Variation in mineral properties in normal and mutant bones and teeth. Cells Tissues Organs. 2005; 181 (3-4): 144-153.

5. Duailibi M.T., Duailibi S.E., Young C.S., Bartlett J.D., et al. Bioengineered teeth from cultured rat tooth bud cells. J Dent Res. 2004; 83 (7): 523-528.

6. Nudelman F., Pieterse K., George A. et al. The role of collagen in bone apatite formation in the presence of hydroxyapatite nucleation inhibitors. Nat Mater. 2010; 9 (12): 1004-1009.

7. Dorozhkin S., Epple M. Biological and medical significance of calcium phosphates. Angew Chem Int Ed Engl. 2002; 41 (17): 3130-3146.

8. Gasyuk A.P., Shepit'ko V.I., Zhdan V.M. Morfo- i gistogenez osnovnykh stomatologicheskikh zabolevaniy. [Morpho- and histogenesis of major dental diseases]. Poltava. 2008, 93 s. (in Russian).

9. Gasyuk A.P., Novosel'tseva T.V., Kostirenko A.P. Osobyye epimikroskopichekiye struktury emali i dentina zuba.. [Special epimictoscopic structures of tooth enamel and dentin]. Visnyk problem biolohiyi i medytsyny. 2013; 104 (1): 251-253. (in Russian).

10. Zaytsev A.V., Vatsenko A.V., Kostirenko A.P. Al'ternativnyye interpretatsii uchenykh raznykh nauchnykh shkol v ustanovlenii pravil'nogo opredeleniya ponyatiya «kariyes» v stomatologii. [Alternative interpretations of scientists from different scientific schools in establishing the correct definition of the concept of «caries» in dentistry]. Visnyk problem biolohiyi i medytsyny. 2012; 93 (2): 22-25. (in Russian).

11. Kostyrenko 0.P., Kotelevs'ka N.V., Netrebovs'ka 0.V. Morfolohiya pryshyykovoyi dilyanky zuba v aspekti hiperesteziyi. [Morphology of the cervical tooth in terms of hyperesthesia]. V: Ternopil Dental Summit: materialy nauk.-prakt. konf. z mizhnar. uchastyu prysvyachenoyi 60-ty richchyu DVNZ «TDMU im. I.YA. Horbachevs'koho MOZ Ukrayiny», 1-2 cherv 2017 r., Ternopil. 2017; 95-97. (in Ukrainian).

12. Gasyuk P.A., Vorobets A.B., Kostyrenko A.P. et al. Morfogenez prekarioznykh protsessov v emali i dentine bol'shikh korennykh zubov cheloveka. Matematicheskaya morfologiya. [Morphogenesis of precariotic processes in enamel and dentin of large molars of a person. Mathematical morphology]. Elektronnyy matematicheskiy i medikobiologicheskiy zhurnal. 2015; 14 (2): 1-8. (in Russian).
13. Novosel'tseva T.V., Neporada K.S., Kostyrenko A.P. Gistokhimicheskiye osobennosti stroyeniya dentina zuba. [Histological features of the structure of the dentin of the tooth]. V: Materialy nauchnoprakticheskoy konferentsii s mezhdunarodnym uchastiyem «Gofunskiye chteniya», 10 fevr 2015, Khar'kov. 2015;11(1):181-184. (in Russian).

14. Beniash E. Biominerals-hierarchical nanocomposites: the example of bone wires. Nanomed Nanobiotechnol. 2011; 3 (1): 47-69.

15. Herring S.W., Ochareon P. Bone - special problems of the craniofacial region. Orthod Craniofac Res. 2005; 8 (3): 174-182.

16. Hart S., Hart T. Disorders of human dentin. Cells Tissues Organs. 2007; 186(1): 70-77.

This article was performed as part of research work: "Patterns of morphogenesis of organs, tissues and neurovascular formations in normal condition, pathology and under the influence of exogenous factors"(State registration No. 0118U004457).

\section{ORCID and contributionship:}

Oleksij P. Kostyrenko: 0000-0002-4092-8319 A, E, F

Mykhailo M. Koptev: 0000-0002-3726-8911 A, D, F

Nataliia I. Vynnyk: 0000-0002-1596-0958 ${ }^{\text {B, C, D }}$

Maksym I. Skrypnyk: 0000-0002-9552-4098 B, C,D

Petro A. Hasiuk: 0000-0002-2915-0526 ${ }^{\text {B, D, E }}$

Alevtyna M. Bilous: 0000-0002-7165-0516 ${ }^{\text {B, C, D }}$

Serhii A. Proskurnya: 0000-0003-2675-9843 B, C, D

\section{Conflict of interest:}

The Authors declare no conflict of interest.

\section{CORRESPONDING AUTHOR Alevtyna M. Bilous \\ Ukrainian Medical Stomatological Academy \\ 23 Shevchenko st., 36011 Poltava, Ukraine \\ tel:+380506147637 \\ e-mail:alisa6sh8@gmail.com}

Received: 07.12.2019

Accepted: 22.09 .2020

A - Work concept and design, B - Data collection and analysis, C - Responsibility for statistical analysis, D -Writing the article, $\mathbf{E}$-Critical review, F - Final approval of the article 